\title{
HYDROCHEMICAL ASSESSMENT OF GROUNDWATER QUALITY IN SAGAMU AREA, SOUTHWESTERN NIGERIA
}

\author{
R. O. KAREEM, R. B. ADESINA AND S. O. ADETU
}

(Received 11 November 2015; Revision Accepted 4 December 2015)

\begin{abstract}
Groundwater samples from 39 wells in different geological settings in Sagamu area, Southwestern Nigeria were analysed for their hydrochemical properties, to determine their suitability for domestic and irrigation purposes. The samples were subjected to chemical analysis involving the Induced Coupled Plasma Mass Spectrometry (ICPMS) for cation determination, and volumetric analysis to determine the anions. The classification of the groundwater using Piper diagram, Gibbs variation, Wilcox classification and Zhang evolution plot reveals the distribution of groundwater quality in the area. Parameters like Sodium Absorption Ratio (SAR), Magnesium Adsorption Ratio (MAR) Kelly's Ratio $(\mathrm{KR})$, Permeability Index (PI), Residual Sodium Bicarbonate (RSBC), and chloro-alkaline indices (CAI), were calculated for irrigation purposes. The results were presented as spatial distribution maps for interpretation and further inferences. Comparison of the groundwater quality in the area with local and international standards indicates that $94.9 \%$ of the groundwater within the area is generally suitable for domestic and irrigation purposes.
\end{abstract}

KEYWORDS: Groundwater, hydrochemical assessment, geological settings, Sagamu area, Irrigation.

\section{INTRODUCTION}

Increasing population in Nigeria has further led to the demand of potable and abundant water supply for consumption and irrigation purposes. Sagamu metropolis in Southwestern part of Nigeria is not an exception, as groundwater is a major source of water of the residents for various purposes. Groundwater as an indispensable water resource provides a reasonable constant supply which is not liable to drying out during dry season unlike surface water. Apart from its constant availability, it possesses excellent quality that requires little or no treatment in most cases (Asiwaju-Bello et al. 2013). Its occurrence and quality can be complicated in areas underlain by complex geology where there is contact between Precambrian basement and sedimentary rocks, as the aquifer units are controlled by both primary and secondary porosities.

Naturally, groundwater contains dissolved mineral ions from soil particles, sediments and rocks due to processes including dissolution and ion exchange of infiltrating waters through the pores or fractures of the unsaturated zone and the aquifer. However, human activities can alter the natural composition of groundwater through the introduction of chemical and microbial matter through improper waste management at the land surface. High concentrations of trace metals can also be found in ground water near contaminated sources, posing serious health threats. Toxic chemicals in drinking water may have either acute or chronic health effects, although, they are seldom high enough to cause harm. Hence, it is possible to understand the change in quality due to rock-water interaction or any type of anthropogenic influence. This study, therefore, focuses on the assessment of groundwater evolution and quality in Sagamu area and environs, with regards to its suitability for irrigation and consumption purposes.

\section{GEOLOGY AND HYDROGEOLOGICAL SETTINGS}

The study area is located at a transition zone which is underlain partly by the rocks of the basement complex of Southwestern Nigeria, and the sedimentary formations of the Dahomey Basin. It lies within latitude $6^{0} 49^{\prime}$ to $7^{0} 00^{\prime} \mathrm{N}$ and longitude $3^{0} 35^{\prime}$ to $3^{0} 45^{\prime} \mathrm{E}$ (Fig. 1). The dominant rocks in the Northeastern part of the study area are biotite granite gneiss, porphyroblastic gneiss, porphyritic biotite granite, biotite schist and migmatite (Rahaman, 1976). The remaining southern portion of the area is covered by sedimentary rocks of Dahomey basin. The formations in the basin include: Abeokuta, Ewekoro, llaro and Benin formations (Jones and Hockey, 1964). The major river in the area is River Ona which runs almost North-South and River lbu which flows from the crystalline uplands southward to the coastal lagoon, showing a dendritic to sub-dentritic drainage pattern. Groundwater occurrence in the northern parts of the study area is limited to the fractured and in-situ weathered portions of the rocks. The aquifer occurs within the in-situ weathered portion which overlies the fresh basement or within fractured fresh rocks.

\footnotetext{
R. O. Kareem, Soadleo Global Resources Nig. Ltd., Lagos State, Nigeria.

R. B. Adesina, Department of Marine Science and Technology, Federal University of Technology, PMB 704, Akure, Nigeria.
}

S. O. Adetu, Soadleo Global Resources Nig. Ltd., Lagos State, Nigeria. 


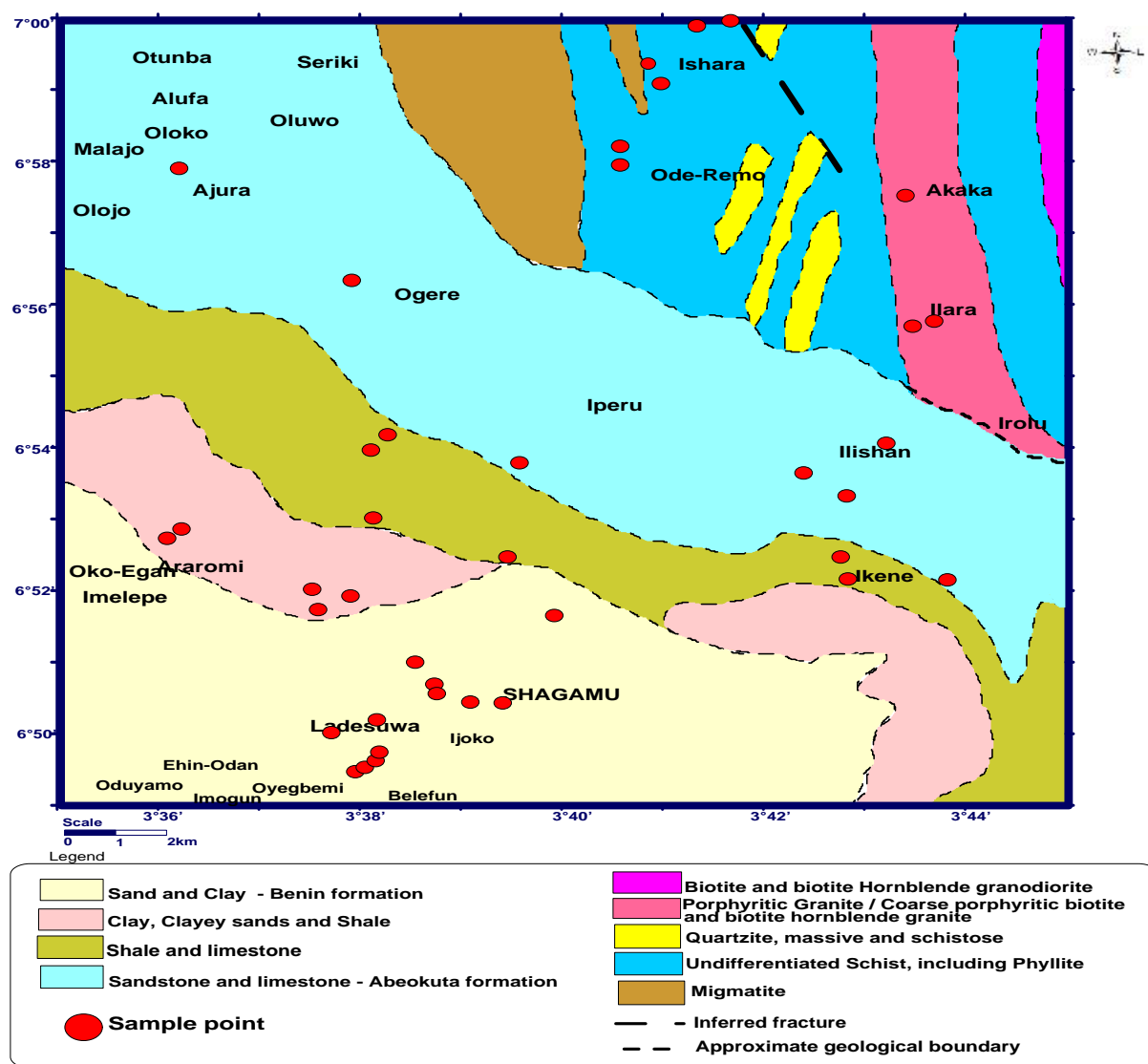

Fig 1: Geological Map of the study area showing sampling points (Modified from Carter, 1964)

\section{PREVIOUS WORKS}

A number of studies on groundwater quality with respect to their suitability for consumption and irrigation have been carried out within and outside Nigeria. These studies show that shallow aquifers in Nigeria are potentially vulnerable to pollution from agricultural (fertilisers), domestic (waste dumps, latrines) and industrial sources, except where surface layers are of poor permeability and can afford some protection of the underlying aquifers.

Abimbola et al. (1999) characterised water from both sedimentary and basement for groundwater quality in Abeokuta area of Southwestern Nigeria, as $\mathrm{Ca}-\mathrm{HCO}_{3}$ type with low TDS. The chemical parameters of the water from both geological settings fall within the limit for water quality standards for drinking, but with questionable consideration owing to high colliform content.

Jalali and Khanlari (2007) investigated the hydrochemical composition of groundwater in Damagh area, Western Iran, to determine their quality. The chemical facies of the groundwater is related to the interaction of the geology of the area with the cation exchange between the groundwater and clay minerals, and anthropogenic activities.

Gupta et al. (2008) carried out a hydrochemical analysis of groundwater in Burdwan District, West Bengal, India, to determine its suitability for drinking and irrigation purposes. The chemical relationships of the groundwater are controlled by rock dominance. The groundwater in the area is suitable for consumption according to standards, while some areas show high salinity and SAR, which is a setback to their usage for irrigation.

Obiefuna and Orazulike (2010) determined the most important dissolved ions in groundwater that will influence irrigation in Yola area of Northern Nigeria. The results from the various irrigation indices showed that the groundwater will neither cause salinity hazards nor will it have adverse effects on the soil properties of the study area.

Asiwaju-Bello et al. (2013) assessed the hydrochemical property of groundwater in Akure area, South-western Nigeria for irrigation purposes. The results show that $92.3 \%$ of 103 well samples analysed gave a positive chloro-alkaline index ratios, signifying direct ionexchange of $\mathrm{Na} / \mathrm{K}$ in water with $\mathrm{Mg} / \mathrm{Ca}$ in the host rock. The evaluation and comparison of calculated values of the parameter indices indicate generally good to permissible uses of the groundwater in the area for irrigation.

\section{METHODOLOGY}

Water samples were collected from 39 wells around different geological formations in Sagamu metropolis. Insitu physico-chemical parameters were measured using the PC Tester 35 multi-parameter meter. Samples were preserved using standard specifications prior to laboratory analyses. The samples were subjected to major cations analysis using inductively coupled plasma mass spectrophotometry (ICPMS). Chloride was measured using silver nitrate titration and bicarbonate was measured with acid-base titration, while sulphate was measured using colorimeter-spectrophotometer. $\mathrm{NO}_{3}$ was measured using Transmittance-display 
photometer. The results were analysed to determine their hydrochemical facies and projected graphically using Rockworks software. For irrigation purpose, the following parameters were evaluated from the chemical data using standard equations according to Raghaunath (1987): Sodium Absorption Ratio (SAR), Magnesium Adsorption Ratio (MAR) Kelly's Ratio (KR), Permeability Index (PI), Residual Sodium Bicarbonate (RSBC), and chloro-alkaline indices (CAI).

The equations are:

$\mathrm{SAR}=\frac{\mathrm{Na}^{+}}{\left[\left(\mathrm{Ca}^{2+}+\mathrm{Mg}^{2+}\right) / 2\right]^{0.5}}$
$\mathrm{MAR}=\frac{\mathrm{Mg}^{2+} \times 100}{\left(\mathrm{Ca}^{2+}+\mathrm{Mg}^{2+}\right)}$
$\mathrm{RSBC}=\mathrm{HCO}^{3-}-\mathrm{Ca}^{2+}$
$\mathrm{KR}=\frac{\mathrm{Na}^{+}}{\left(\mathrm{Ca}^{2+}+\mathrm{Mg}^{2+}\right)}$
$\frac{\mathrm{Na}^{+}+\sqrt{ }\left[\mathrm{HCO}^{3-} \times 100\right]}{\mathrm{Ca}^{2+}+\mathrm{Mg}^{2+}+\mathrm{Na}^{+}}$

$\mathrm{CAI}=\frac{\left[\mathrm{Cl}^{-}-\left(\mathrm{Na}^{+}+\mathrm{K}^{+}\right)\right]}{\mathrm{Cl}^{-}}$
All the ionic concentrations are expressed in $\mathrm{meq} / \mathrm{l}$.

\section{RESULTS AND DISCUSSION}

\section{Physico-chemical parameters}

Electrical Conductivity of the groundwater ranges from 23 to 1026 (Table 1), with about $62 \%$ of the study area having conductivity values between $23 \mu \mathrm{S} / \mathrm{cm}$ and $120 \mu \mathrm{S} / \mathrm{cm}$. The large variation in the EC may be attributed to the geochemical processes prevailing in the different geological settings of the area. The TDS values for all the samples in the study area ranges from 17.3$769.5 \mathrm{meq} / \mathrm{l}$ with a mean value of $142.04 \mathrm{meq} / \mathrm{l}$ (Table 1). Higher TDS concentration is observed in Benin formation and the basement aquifers because most of these parts have low groundwater level. This clearly supports the role of direction and amount of groundwater flow for variation in groundwater quality. TDS value of $500 \mathrm{meg} / \mathrm{l}$ is often regarded as the desirable limit, but values of about $1,500 \mathrm{meq} / \mathrm{l}$ is the maximum permissible limit suggested for drinking water (WHO,1993). However, the groundwater were within the permissible limit $(<1,000 \mathrm{meq} / \mathrm{l})$ for irrigation use (Table 2 ), and fall under the non saline category according to Robinove

et

al.

1958.

Table 1: Water Parameter Indices.

\begin{tabular}{|c|c|c|c|c|c|c|c|c|c|c|c|}
\hline Location & $\mathrm{pH}$ & EC & $\begin{array}{l}\text { Temp } \\
\left({ }^{\circ} \mathrm{C}\right)\end{array}$ & $\mathrm{TH}$ & TDS & SAR & RSBC & $\mathrm{KR}$ & PI & MAR & CAI \\
\hline Basement B1 & 7.4 & 310 & 27.6 & 172.1 & 232.5 & 0.2 & -2.5 & 0.4 & 2.7 & 6.0 & -4.1 \\
\hline B2 & 8.0 & 85 & 27.0 & 14.5 & 63.8 & 0.4 & -0.1 & 3.0 & 3.8 & 76.6 & -2.6 \\
\hline B3 & 8.2 & 861 & 28.3 & 209.1 & 645.8 & 0.8 & -2.7 & 2.6 & 3.4 & 52.7 & -21.9 \\
\hline B4 & 7.4 & 89 & 28.1 & 30.9 & 66.8 & 0.2 & -0.4 & 0.9 & 3.0 & 51.4 & -1.8 \\
\hline B5 & 7.5 & 309 & 28.5 & 116.8 & 231.8 & 0.3 & -1.5 & 1.4 & 1.4 & 57.9 & -5.8 \\
\hline B6 & 7.5 & 80 & 27.0 & 44.8 & 60.0 & 0.0 & -0.8 & 0.1 & 2.4 & 4.7 & -0.3 \\
\hline B7 & 7.5 & 244 & 29.0 & 55.2 & 183.0 & 0.5 & -0.6 & 1.9 & 2.1 & 64.6 & -11.9 \\
\hline B8 & 7.0 & 60 & 29.3 & 20.1 & 45.0 & 0.2 & -0.3 & 0.9 & 4.0 & 25.1 & -1.8 \\
\hline B9 & 7.1 & 184 & 29.2 & 59.3 & 138.0 & 0.2 & -1.0 & 0.5 & 1.6 & 15.7 & -11.1 \\
\hline Abeokuta fm. A1 & 7.1 & 151 & 27.5 & 30.6 & 113.3 & 0.4 & -0.3 & 1.9 & 2.4 & 77.4 & -1.5 \\
\hline A2 & 7.2 & 33 & 28.4 & 5.8 & 24.8 & 0.4 & 0.0 & 4.2 & 4.5 & 71.5 & -1.6 \\
\hline A3 & 7.1 & 102 & 30.9 & 12.9 & 76.5 & 0.8 & -0.1 & 5.2 & 2.9 & 62.6 & -7.8 \\
\hline A4 & 7.0 & 76 & 27.9 & 19.1 & 57.0 & 0.2 & -0.2 & 1.2 & 3.0 & 65.4 & -3.1 \\
\hline A5 & 6.4 & 73 & 26.7 & 15.2 & 54.8 & 0.3 & -0.1 & 2.0 & 4.0 & 76.6 & -1.4 \\
\hline A6 & 6.7 & 23 & 28.4 & 3.3 & 17.3 & 0.3 & 0.0 & 3.8 & 9.2 & 75.0 & -0.3 \\
\hline A7 & 7.1 & 103 & 28.8 & 8.1 & 77.3 & 0.3 & -0.1 & 2.1 & 4.7 & 54.6 & 0.6 \\
\hline Ewekoro fm. E1 & 6.6 & 69 & 28.1 & 13.0 & 51.8 & 0.5 & -0.1 & 3.2 & 3.2 & 73.4 & -3.1 \\
\hline E2 & 6.9 & 63 & 28.4 & 11.0 & 47.3 & 0.3 & -0.1 & 1.9 & 4.0 & 69.3 & -1.9 \\
\hline E3 & 6.9 & 37 & 28.4 & 5.4 & 27.8 & 0.4 & 0.0 & 4.0 & 4.7 & 57.2 & -1.3 \\
\hline E4 & 7.0 & 78 & 32.3 & 28.3 & 58.5 & 0.2 & -0.3 & 0.9 & 2.4 & 67.9 & -3.1 \\
\hline E5 & 7.1 & 186 & 28.7 & 100.1 & 139.5 & 0.1 & -1.7 & 0.4 & 1.2 & 17.2 & -0.5 \\
\hline E6 & 7.1 & 50 & 28.9 & 8.6 & 37.5 & 0.2 & -0.1 & 1.3 & 7.6 & 30.8 & -0.01 \\
\hline Ilaro fm. IF1 & 7.3 & 40 & 30.7 & 11.8 & 30.0 & 0.2 & -0.2 & 0.9 & 4.8 & 14.3 & -1.3 \\
\hline IF2 & 6.3 & 55 & 28.6 & 24.6 & 41.3 & 0.1 & -0.4 & 0.4 & 3.6 & 8.9 & -1.1 \\
\hline IF3 & 6.9 & 48 & 29.9 & 9.6 & 36.0 & 0.2 & -0.1 & 2.0 & 4.4 & 81.9 & -0.9 \\
\hline IF4 & 7.4 & 147 & 27.5 & 73.1 & 110.3 & 0.1 & -1.3 & 0.3 & 1.6 & 9.0 & -2.6 \\
\hline IF5 & 6.4 & 67 & 27.0 & 28.7 & 50.3 & 0.1 & -0.5 & 0.3 & 2.5 & 7.6 & -0.5 \\
\hline Benin fm. BF1 & 7.5 & 828 & 23.6 & 175.8 & 621.0 & 1.4 & -2.1 & 3.6 & 5.7 & 55.6 & -19.5 \\
\hline BF2 & 7.9 & 1026 & 27.8 & 217.7 & 769.5 & 1.7 & -2.9 & 3.9 & 6.9 & 53.0 & -13.3 \\
\hline BF3 & 6.9 & 402 & 26.6 & 188.0 & 301.5 & 0.1 & -3.5 & 0.3 & 1.0 & 4.9 & -9.6 \\
\hline BF4 & 7.4 & 100 & 30.2 & 18.0 & 75.0 & 0.5 & -0.2 & 2.7 & 1.6 & 68.3 & -15.5 \\
\hline BF5 & 6.6 & 39 & 31.6 & 9.9 & 29.3 & 0.2 & -0.1 & 1.2 & 6.2 & 33.4 & -0.9 \\
\hline BF6 & 7.5 & 500 & 28.3 & 75.9 & 375.0 & 1.2 & -0.9 & 3.7 & 3.4 & 58.9 & -23.2 \\
\hline
\end{tabular}




\begin{tabular}{|l|l|l|l|l|l|l|l|l|l|l|l|}
\hline BF7 & 7.6 & 40 & 28.7 & 83.3 & 30.0 & 0.8 & -1.3 & 1.8 & 2.6 & 22.2 & -18.4 \\
\hline BF8 & 8.4 & 868 & 28.2 & 8.2 & 651.0 & 0.7 & -0.1 & 4.0 & 2.9 & 21.5 & -3.4 \\
\hline BF9 & 8.2 & 422 & 28.9 & 24.1 & 316.5 & 2.3 & -0.2 & 12. & 4.1 & 81.7 & -35.2 \\
\hline BF10 & 7.4 & 170 & 28.7 & 35.1 & 127.5 & 0.6 & -0.5 & 2.2 & 2.0 & 37.4 & -4.4 \\
\hline BF11 & 8.3 & 782 & 29.7 & 137.2 & 586.5 & 1.0 & -1.6 & 3.2 & 3.7 & 71.3 & -26.7 \\
\hline BF12 & 7.6 & 437 & 30.0 & 67.4 & 327.8 & 1.1 & -0.7 & 4.1 & 3.1 & 83.0 & -9.6 \\
\hline
\end{tabular}

Table 2: Limits of Some Parameter Indices for Rating Irrigation Water Quality (After Eaton, 1950)

\begin{tabular}{|l|l|l|l|l|}
\hline Category & $\mathrm{EC}(\mu \mathrm{s} / \mathrm{cm})$ & $\mathrm{RSBC}$ & $\mathrm{SAR}$ & SSP \\
\hline 1- Excellent & $<250$ & $<1.25$ & $<10$ & $<20$ \\
\hline 2- Good & $250-750$ & $1.25-2.5$ & $10-18$ & $20-40$ \\
\hline 3- Doubtful & $750-2250$ & $>2.5$ & $18-26$ & $40-80$ \\
\hline 4- Poor & $>2250$ & & $>26$ & $>80$ \\
\hline
\end{tabular}

Table 3: Quality of Irrigation Water in Relation to EC (After Richards, 1954)

\begin{tabular}{|l|l|l|l|}
\hline $\mathrm{S} / \mathrm{N}$ & $\mathrm{EC}(\mu \mathrm{s} / \mathrm{cm})$ & Water Type & Suitability for Irrigation \\
\hline 1 & $<250$ & Low saline water & Entirely safe \\
\hline 2 & $250-750$ & Moderately saline & Safe under practically all conditions \\
\hline 3 & $750-2250$ & Medium to high salinity & $\begin{array}{c}\text { Safe with only permeable soil and } \\
\text { moderate leaching }\end{array}$ \\
\hline 4 & $2250-4000$ & High salinity & Unfair for irrigation \\
\hline 5 & $4000-6000$ & Very high salinity & Unfair for irrigation \\
\hline 6 & $>6000$ & Excessive salinity & Unfair for irrigation \\
\hline
\end{tabular}

Based on Wilcox (1950) classification chart (Fig. 4), most of the samples in the study area have low SAR indicating their suitability for irrigation and domestic use. Also, the $\mathrm{pH}$ of groundwater in the study area ranges from 6.4 to 8.3 which fall within the WHO standard for drinking water as a range of 6.5 to 8.5 is normally acceptable.

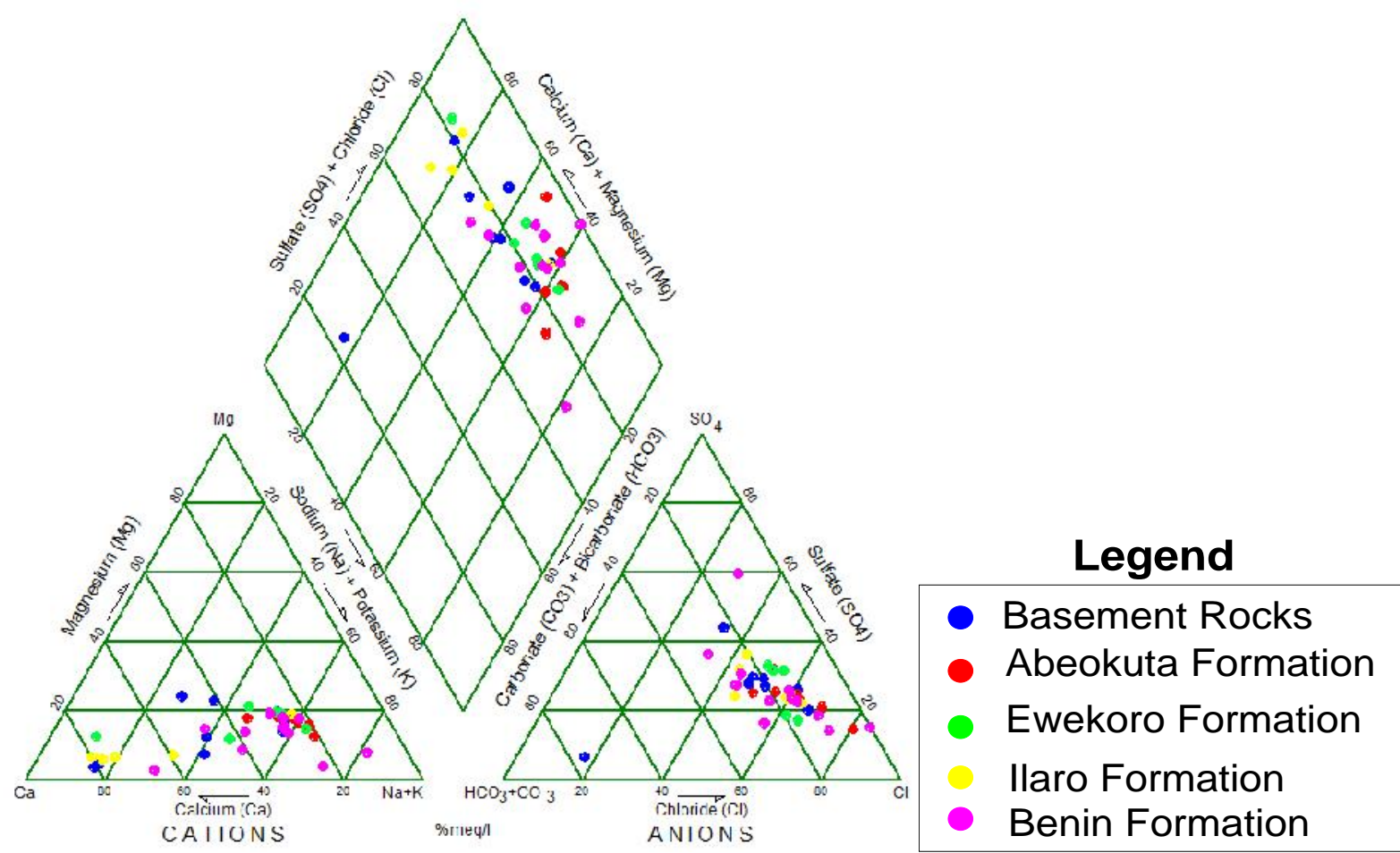

Fig. 2: Distribution of ions in the study area (After Piper, 1953)

\section{Hydrochemical facies of the groundwater}

The Piper diagram (Piper, 1953) was used to infer the hydrochemical facies of the groundwater (Fig. 2). The hydrochemical analysis revealed the order of abundance of elements as revealed by their mean concentration values as $\mathrm{HCO}_{3}>\mathrm{SO}_{4}>\mathrm{NO}_{3}>\mathrm{Cl}$ for anion and $\mathrm{Ca}+>\mathrm{K}+>\mathrm{Mg}^{2+}>\mathrm{Na}$ for both urban and peri- urban areas in the 5 Formations. The facies (Fig. 2) reveals three water types viz: $\mathrm{Ca}-\left(\mathrm{SO}_{4}\right)-\mathrm{Cl}$, typifying sedimentary origin; $\mathrm{Ca}-(\mathrm{K})-\mathrm{SO}_{4}-\mathrm{Cl}$ showing water from transition 
zones and the third type $\mathrm{Ca}-\mathrm{HCO}_{3}$ typifying basement origin (Piper, 1953). The groundwater in the area is generally alkali types suggesting the addition of chlorine and sulphate base disinfectants to the water or sewage

\section{Groundwater evolution in the study area}

The mechanism of groundwater evolution classification of groundwater in the study area using Zhang plot reveals two types (Fig. 3). Type-A represents the fresh groundwater which interacted with the region dominated by sodium rich minerals within the weathered regolith in which the Calcium content of the water has been replaced by base exchange process Type-B has a high TDS generally above 500mg/l due to high total system in the area and the resultant weathering and dissolution of bedrock units. The $\mathrm{Ca}-\mathrm{HCO}_{3}$ type is typical of waters in the basement complex of Nigeria as a result of cation exchange (Tijani, 1994). dissolved ions (TDI) as a result of ions combination to produce $\mathrm{Ca}-(\mathrm{Mg}, \mathrm{Na})-\mathrm{HCO}_{3}$ water.

The Gibbs' diagram (Fig. 4) reveals that the chemistry of the groundwater is influenced by their geology. Water chemistry from the basement is influenced by geogenic activities, while Abeokuta and Ewekoro formations are influenced by both geogenic and anthropogenic activities. Samples from llaro formation show the influence of mineral precipitation or weathering activities, while $75 \%$ of samples in Benin formation are controlled by dilution.

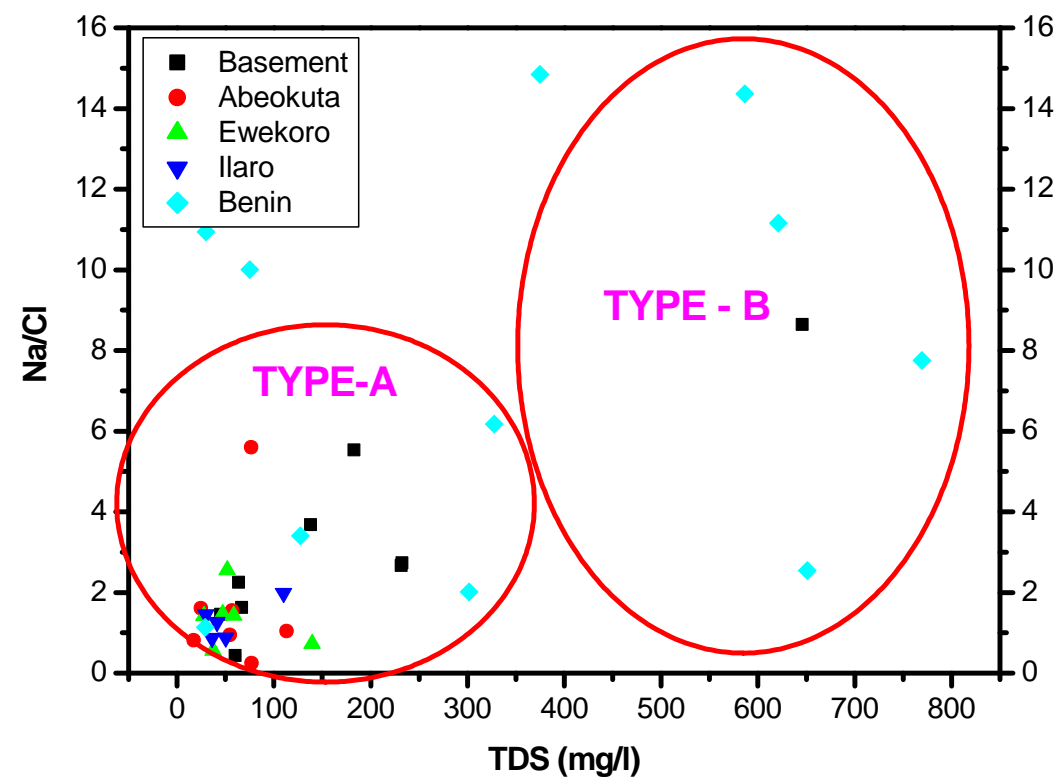

Fig. 3: Groundwater evolution plot of the area (After Zhang, 2008)

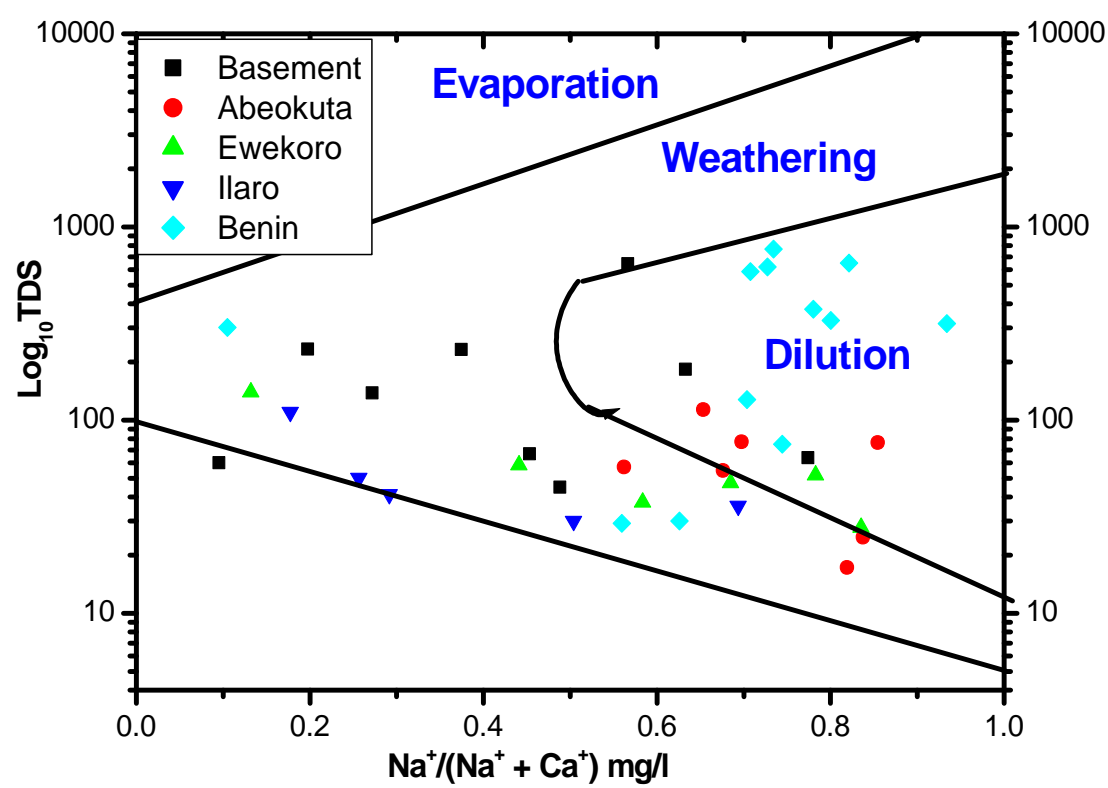

Figure 4: Gibbs' diagram of water in the study area (After Gibbs, 1970) 
100

1000

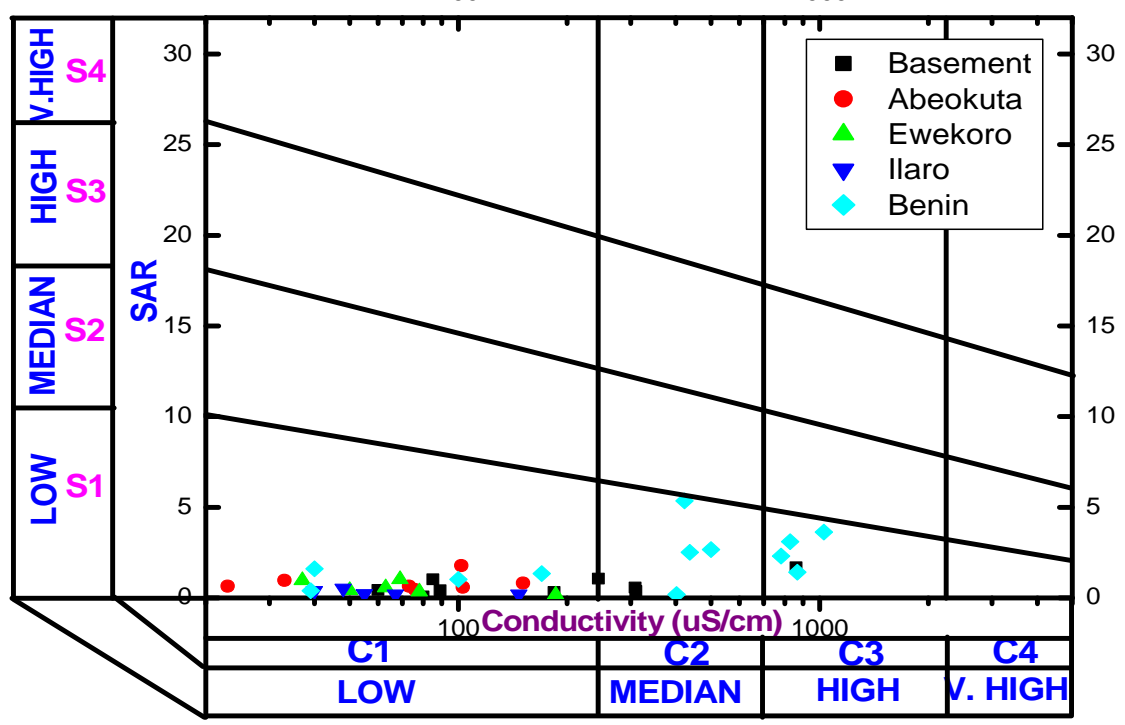

Fig. 5: Wilcox diagram of the study area.

\section{Ionic concentrations of the groundwater}

Calcium, Magnesium and total hardness in water are inter-related and hence combined in the description for groundwater hardness (Table 1). In the study area, the total hardness ranges from 5.8 to $217.7 \mathrm{meq} / \mathrm{l}$., which is below the recommended limit of $300 \mathrm{meq} / \mathrm{l}$ for potable water according to WHO, 1993. The chloride, sulphate, nitrate, and phosphate concentration of groundwater in the study area ranges from $1.2 \mathrm{meq} / \mathrm{l}$ to $20.45 \mathrm{meq} / \mathrm{l}, 2.09$ to $5.184 \mathrm{meq} / \mathrm{l}, 7.50$ to $10.28 \mathrm{meq} / \mathrm{l}$ and $4.3 \mathrm{meq} / \mathrm{l}$ to $6.89 \mathrm{meq} / \mathrm{l}$ respectively. These values also fall within the recommended limits with maximum values of $250 \mathrm{meq} / \mathrm{l}$, $150 \mathrm{meq} / \mathrm{l}, 45 \mathrm{mg} / \mathrm{l}$ and 0.025 for chloride, sulphate, nitrate, and phosphate respectively, for potable drinking water.

\section{Irrigation groundwater quality indices}

The residual sodium bicarbonate (RSBC) ranges from 3.52 to $+0.002 \mathrm{meq} / \mathrm{l}$, and the SAR ratio ranges from 0.1 2.3, which according to Eaton (1950) are categorised as excellent for irrigation (Table 2). Permeability index (PI) used to assess the probable influence of water quality on physical properties of soils range from $1.4 \%$ to $9.2 \%$ (Table 1) and the results indicate that groundwater in the study area fall within class I and class II (Doneen, 1966) which make the water suitable for irrigation purposes. According to Kelly et al (1940), about $48.7 \%$ of the sampled area is not suitable for irrigation since they have KR values above 2 (Table 1). The values of MAR for all the groundwater samples vary from $4.7-83 \%$ (Tables 1) with $46.15 \%$ of the waters having MAR less than the acceptable limit of $50 \%$ (Ayers \& Westcot, 1985), which may be mentioned that most of the samples exceeds $50 \%$ and requires suitable measures to avoid magnesium hazard. About $97.44 \%$ of the samples gave negative Chloro-Alkaline index (CAI) ratios, reflecting an indirect ion-exchange of $\mathrm{Na} / \mathrm{K}$ in the water with $\mathrm{Mg} / \mathrm{Ca}$ in the host rock. The result of water quality index prepared according to the National Sanitation Foundation Water Quality Index (NSFWQI) shows that the groundwater is of medium quality, which is good for consumption.

\section{CONCLUSION}

The result of the physico-chemical analyses and the calculated irrigation water quality indices of groundwater from wells in Sagamu area show that the groundwater is generally suitable for domestic and irrigation purposes. Although, the water quality of groundwater in the study area varies across the different geological terrain, a comparison of the groundwater with local and international standards indicates that $94.9 \%$ of the groundwater is generally suitable for domestic and irrigation purposes. The remaining $5.1 \%$ of the analysed waters were found to be polluted through anthropogenic means, and they fall within the permissible to unsuitable for domestic and irrigation purposes. However, detailed hydrochemical investigations should be carried out for large scale irrigation scheme.

\section{REFERENCES}

Abimbola, A. F., Tijani, M. N and Nurudeen, A., 1999. Some aspects of groundwater quality assessment of Abekuta. Jour. Min. Geo. 32, (1): 23-32.

Asiwaju-Bello, Y. A., Olabode, F. O., Duvbiama, O. A., lyamu, J. O, Adeyemo, A. A and Onigbinde, M. T., 2013. Hydrochemical Evaluation of Groundwater in Akure Area, Southwestern Nigeria, for Irrigation Purpose. European International Journal of Science and Technology 2, (8): 235-249.

Ayers, R. S and Westcot, D. W., 1985. Water quality for agriculture FAO Irrigation and Drain Paper No. 29, (1): 1-109.

Carter J. D., 1964. Geological map of Nigeria Scale $1: 2,000,000$

Doneen, L, D., 1966. Water quality requirement for agriculture. Proc. National Sym. Quality Standards for Natural Waters. University of Michigan, Ann. Report, 213- 218. 
Eaton, F. M., 1950. Significance of carbonate in irrigation waters. Soil Science, 67, (3): 128-133.

Gibbs, R. J., 1970. Mechanisms controlling world water chemistry. Science 17:1088-1090.

Gupta, S., Mahato, A., Roy, P., Datta J. K and Saha, R. N., 2008. Geochemistry of groundwater, Burdwan District, West Bengal, India In. Environ Geol (2008) 53:1271-1282.

Jalali, M and Khanlari, Z. V., 2007. Major ion chemistry of groundwaters in the Damagh area, Hamadan, western Iran. Environ Geol 54:87-93 DOI 10.1007/s00254-007-0795-6.

Jones, H. A and Hockey, R. D., 1964. The Geology of part of Southwestern Nigeria, GSN Bulletin No. 31- 101.

Kelly, W. P., Brown, S. M and Liebig, G. F. Jr., 1940. Chemical effects of saline irrigation water on soil; Soil science 49, 95-107.

Obiefuna, G. I and Orazulike, D. M., 2010. Assessment of groundwater quality of Yola area for irrigation purposes. Water Resources. J. Nigerian Assoc. Hydrogeol., 20, (1): 32-52.

Piper, A. M., 1953. A graphic procedure in the chemical interpretation of water analysis. US Geological Survey Groundwater Note 12.

Raghaunath, I. M., 1987. Groundwater. Second edition. Wiley Eastern Ltd, New Delhi, India.
Rahaman, M. N., 1976. Review of the basement geology of southwestern Nigeria, in geology of Nigeria, edited by C. A. Kogbe, Elizabethan pub. Co. Lagos. $41-58$.

Robinove, C. J., Longfort, R. H and Brook, J. W., 1958. Saline water resource of North Dakota US Geological Survey Water Supply Paper 1428.

Tijani, M. N., 1994. Hydrogeochemical assessment of groundwater in Moro area, Kwara State, Nigeria, Journal of Environmental Geology. SpringerVerlag 24: 194- 202.

Wilcox, L. V., 1950. Classification and use of irrigation water. USDA Circ. No. 696, Washington DC.

World Health Organization (WHO)., 1993. Guideline for drinking water quality, 2nd end, 1, 188.

Zhang, X. L and Hou L. X., 2008. Use of hydrogeochemistry and environmental isotopes for evaluation of groundwater in Qingshuihe Basin, Northwestern China. Hydrogeology journal, vol. 16: 335-348. 